Tersedia online di: http://ejournal-balitbang.kkp.go.id/index.php/JP
e-mail:jurnalpari@gmail.com
JURNAL PARI
Volume 3 Nomor 1 Juli 2017
p-ISSN: 2502-0730
e-ISSN : 2549-0133

\title{
PRODUKTIVITAS DAN KOLABORASI PENELITI PADA JURNAL RISET AKUAKULTUR 2011-2015
}

\author{
Productivity And Research Collaboration In The Aquaculture Research Journal \\ ERNY PUSPA \\ Pusat Riset Perikanan
}

Diterima tanggal : 20 April 2017 diterima setelah perbaikan : 22 Mei 2017 disetujui terbit : 11 Juni 2017

\begin{abstract}
ABSTRAK
Penelitian ini bertujuan untuk mengetahui produktivitas penulis paling produktif dan tingkat kolaborasi terbanyak dalam penulisan pada Jurnal Riset Akuakultur tahun 2011-2015. Penelitian dilakukan dengan metode deskriptif menggunaan data publikasi Jurnal Riset Akuakultur periode tahun 2011-2015 yang memuat 240 artikel. Hasil penelitian menunjukkan bahwa I Nyoman Radiarta merupakan penulis paling produktif (23 artikel), kemudian A. Mariana Lusiastuti (18 artikel). Tingkat kolaborasi penulis terbanyak dihasilkan oleh I Nyoman Radiarta (23 artikel), kemudian oleh A. Mariana Lusiastuti (17 artikel). Tingkat kolaborasi penulisan karya ilmiah pada Jurnal Riset Akuakultur yaitu jumlah $\mathrm{C}=0$ sebanyak 3 penulis, $0<C<0,5$ sebanyak 0 penulis, $C=0,5$ sebanyak 0 penulis, $0,5<C<1$ sebanyak 1 penulis dan $C=1$ sebanyak 297 penulis. Adapun rata-rata tingkat kolaborasi sebesar 0,995 (99.5\%). Kondisi ini menunjukkan atmosfer menulis yang baik dan perlu ditingkatkan dikemudian hari.
\end{abstract}

Kata Kunci: Produktivitas, Kolaborasi, Jurnal IImiah

\section{ABSTRACT}

This study aims to determine the productivity and the level of collaboration in writing in the Journal of Aquaculture Research in 2011-2015. The descriptive method was used to investigate the publication data of Aquaculture Research Journal of 2011-2015 which is containing 240 articles. The results showed that I Nyoman Radiarta was the most prolific writer (23 articles), followed by A. Mariana Lusiastuti (18 articles). The similar result on the author collaboration showed that I Nyoman Radiarta (23 articles), followed by by A. Mariana Lusiastuti (17 articles) have the highest level. Moreover, the level of collaboration (C) writing scientific papers on the Journal of Aquaculture Research was $C=0$ by 3 authors, $0<C<0,5$ by 0 authors, $C=0,5$ as many as 0 authors, $0.5<C<1$ for 1 author and $C=1$ of 297 authors. The average level of collaboration was 0.995 (99.5\%). This condition revealed that the level of collaboration among author in writing Aquaculture Research Journal was appropriate and should be encouraged in the future.

Keywords: Productivity, Collaboration, Scientific Journal

Korespondensi penulis:

Gedung BRSDM II It.2 Jl. Pasir Putih II, Ancol, Jakarta Utara

Email : erny.puslitbangkan@gmail.com 


\section{PENDAHULUAN}

Inti dari suatu penelitian agar mendapatkan jawaban dari permasalahan yang diteliti dan upaya pemecahannya. Dalam melakukan penelitian dapat dilakukan secara perseorangan (individu) maupun kelompok (kolaborasi) dalam bidang ilmu apapun juga.

Kolaborasi penelitian dilakukan apabila permasalahan bersifat kompleks dan tidak dapat dikerjakan secara individu maka diperlukan kerjasama dalam bidang lain dalam memecahkan permasalahantersebut, sebagaimana dikemukakan Prihantono (2002) untuk menanggulangi permasalahan yang semakin kompleks perlu melakukan kerja sama dengan didasarkan berbagai latar belakang keahlian. Melalui kerja sama permasalahan dalam penelitian dapat dipecahkan dan sekaligus dapat menciptakan hasil penelitian yang baik. Kerja sama dalam kegiatan penelitian disebut juga kolaborasi. Sedangkan menurut Katz dan Martin (1997) "Kolaborasi terjadi apabila lebih dari satu orang atau lembaga bekerja sama dalam suatu kegiatan penelitian dengan memberikan sumbangan dalam bentuk ilmu pengetahuan dan tindakan bersifat intelektual maupun material. Dengan adanya kolaborasi diharapkan permasalahan dapat dipecahkan dan bisa menciptakan hasil penelitian yang baik karena adanya perpaduan ilmu dan pengetahuan di antara peneliti yang berkolaborasi “

Manfaat kolaborasi Katz dan Martin menjelaskan (Sormin 2009), bahwa manfaat antara lain terciptanya kesempatan untuk berbagi pengetahuan, keahlian dan teknik tertentu dalam sebuah ilmu. Selain itu kolaborasi dapat meningkatkan kualitas dan kuantitas hasil karya tulis dan meningkatkan produktivitas penulis dengan banyaknya karya tulis ilmiah yang dihasilkan dan diterbitkan melalui media penerbitan elektronik maupun tercetak seperti diterbitkan pada Jurnal Riset Akuakultur

Jurnal Riset Akuakultur merupakan jurnal ilmiah diterbitkan oleh Pusat Riset Perikanan Kementerian Kelautan dan Perikanan, dengan kala terbit 3 kali dalam setahun Jurnal berakreditasi A ini merupakan wadah bagi penulis/peneliti dalam mengapresiasikan karya tulis ilmiahmya khusunya bidang perikanan budidaya baik secara individu maupun secara berkolaborasi.

Berdasarkan uraian di atas maka penulis akan membahas tentang produktivitas dan kolaborasi peneliti pada Jurnal Riset Akuakultur periode tahun 2011 hingga 2015. Dipilihnya Jurnal Riset Akuakultur karena alasan tingkat kolaborasi yang diperkirakan lebih tinggi dibandingkan umumnya. Adapun tujuan dari penelitian ini adalah untuk mengetahui penulis yang paling produktiv dan tingkat kolaborasi terbanyak dalam penulisan ilmiah pada Jurnal Riset Akuakultur periode 2011-2015

\section{TINJAUAN PUSTAKA}

\section{Produktivitas}

Produktifitas menurut kamus besar bahasa Indonesia 2016 adalah kemampuan untuk menghasilkan sesuatu. Salah satu bentuk produktifitas penulis yaitu dengan dapat menghasilkan banyak karya tulis yang berkualitas dan berkuantitas. Produktivitas penullis adalah banyaknya karya tulis yang dihasilkan oleh seseorang secara individual dalam subjek tertentu dan diterbitkan pada jurnal-jurnal ilmiah dalam subjek yang bersangkutan dalam kurun waktu tertentu.(Mustangimah, 2002).

Tingkat produktivitas dipengaruhi tingginya tingkat kolaborasi, semakin banyak penulis berkolaborasi semakin berkualitas tulisannya dan semakin meningkat produktivitasnya, sebagaimana pendapat Sormin (2009) yang menyatakan: Semakin sering peneliti berkolaborasi maka kualitas dan kuantitas karya tulis ilmiah yang dipublikasikan akan semakin bermutu. Hal tersebut dapat terjadi karena adanya dorongan atau motivasi pertukaran ide dan interaksi antara peneliti bersangkutan dengan ilmuwan lain yang mampu menambah wawasan dan perspektif baru bagi peneliti yang melakukan kolaborasi. Di samping itu, kolaborasi juga mampu mendorong kreativitas dari peneliti untuk terus berkreasi dalam penelitian dan penulisan.

Penghitungan tingkat produktivitas penulis pada jurnal ilmiah dilakukan agar dapat mengetahui jurnal yang memiliki penulis-penulis produktif dan siapakah pengarang yang paling produktif dalam menghasilkan karya ilmiah dalam kurun waktu tertentu (Himma\& Fitri, 2009). Dengan demikianpenghitungan produktivitas penulis mempunyai tujuan untuk memberikan pengetahuan tentang berbagai hal seperti mengenai kepengarangan, baik produktivitas pengarang, karakteristik pengarang hingga subjek yang terbanyak (Sri Wulan, 2014) 


\section{Kolaborasi}

Istilah kolaborasi merupakan terjemahan dari kata collaboration yang artinya kerjasama antara lebih dari satu orang atau lebih dari satu lembaga dalam sebuah kegiatan, baik kegiatan penelitian maupun pendidikan (Sulistyo-Basuki, 1990)

Proses kolaborasi dilakukan dengan meminta bantuan orang lain atau secara bekerjasama dalam melakukan kegiatan dikarenan keterbatasan kemampuan untuk melakukan sendiri, seperti membuat tulisan penelitian diperlukan bantuan orang lain untuk berkontribusi dalam masukan, ide, disiplin ilmu pengetahuan yang tidak dikuasai dan sebagainya, sebagaimana Alwasilah (2007) mengatakan bahwa, pengertian kolaborasi adalah suatu teknik pengajaran menulis dengan melibatkan sejawat untuk saling mengoreksi. Kolaborasi adalah ajang bertegur sapa dan bersilaturahmi ilmu pengetahuan. Selain itu ada pembelajaran berjamaah/bersama (social learning). Salah satu prinsipnya adalah bahwa setiap orang memiliki kelebihan tersendiri.

Katz dan Martin (1997) memberikan batasan bahwa seorang peneliti dapat dikatakan atau disebut berkolaborasi (kolaborator) apabila orang tersebut bekerja sama dalam suatu penelitian dan ikut memberikan kontribusi penting berkali-kali; namanya muncul dalam proposal penelitian asli; bertanggung jawab pada satu atau lebih elemen utama penelitian, pelaksanaan eksperimen, analisis dan interpretasi data, penulisan laporan hasil penelitian; bertanggung jawab pada tahap-tahap penting penelitian (pencetus ide, hipotesis asli, atau interpretasi teori); dan sebagai pemilik proposal proyek asli atau penyandang dana, meskipun kontribusi utamanya hanya pada manajemen penelitian (misalnya ketua tim) bukan pada penelitiannya. Mereka yang tidak termasuk kolaborator adalah orang yang memberikan kontribusi relatif sedikit dalam proses penelitian dan teknisi atau asisten peneliti.

Berdasarkan uraian diatas dapat disimpulkan dengan berkolaborasi membentuk kegiatan secara bekerjasama, bertanggung jawab, saling memotivasi, dan saling koreksi, saling berkontribusi sehingga mendapatkan hasil karya tulis yang berkualitas.

\section{Jurnal IImiah}

Jurnal ilmiah adalah majalah publikasi yang memuat KTI (Karya Tulis IImiah) yang secara nyata mengandung data dan informasi yang mengajukan iptek dan ditulis sesuai dengan kaidah-kaidah penulisan ilmiah serta diterbitkan secara berkala. (Hakim, 2012)

Jurnal ilmiah merupakan salah satu contoh terbitan berkala atau berseri. Menurut SulistyoBasuki (1991) terbitan berkala merupakan terbitan yang keluar dalam bagian secara berturut-turut dengan menggunakan nomor urut. Menurut Lasa (1990) berdasarkan kata "periodicals" atau periodik yang diartikan sebagai majalah, terbitan berkala, berisi banyak artikel yang ditulis beberapa orang,diterbitkan oleh lembaga, instansi, yayasan, maupun perkumpulan yang membentuksusunan redaksi sebagai penanggung jawab penerbitan ini dan terbit dalam frekuensiwaktu tertentu secara berkesinambungan.

Ciri Ciri Jurnal IImiah : Jurnal IImiah selalu diterbitkan secara berkala, terbit setiap tahun (dinyatakan dengan "Volume") dan dalam setahun bisa terbit lebih dari satu kali (dinyatakan dengan "Nomer"; Diterbitkan oleh lembaga penerbit atau institusi keilmuan (misal: Organisasi Profesi, Perguruan Tinggi, Lembaga Riset, Penerbit, dII); Struktur utama artikel adalah: Judul artikel, Nama Penulis, Abstrak, Isi, Kesimpulan, Daftar Pustaka. (Ajisuraji (2011)

Tujuan Jurnal IImiah menurut Marusic (2009) Tujuan dari Jurnal adalah untuk menyediakan informasi mengenai hasil penelitian terbaru, yang didukung dengan data yang kuat dan komprehensif untuk membuktikan bahwa penelitian tersebut reliabel.

Pada tahun 2012 PDII-LIPI dalam terbitannya yang berjudul 'Pedoman Penerbitan Buku mendifinisikan jurnal sebagai majalah publikasi yang memuat karya tulis ilmiah yang mengandung data dan informasi yang memajukan ilmu pengetahuan dan teknologi dan ditulis sesuai dengan kaidahkaidah penulisan ilmiah serta diterbitkan secara berkala. Majalah/Jurnal ilmiah wajib memenuhi persyaratan administratif sebagai berikut :

1. Memiliki International Standard Serial Number (ISSN).

2. Memiliki mitra bestari paling sedikit 4 (empat) orang.

3. Diterbitkan secara teratur dengan frekuensi paling sedikit dua kali dalam setahun, kecuali majalah ilmiah dengan cakupan keilmuan spesialisasi dengan frekuensi satu kali dalam satu tahun. 
4. Bertiras tiap kali penerbitan paling sedikit berjumlah 300 eksemplar, kecuali majalah ilmiah yang menerbitkan sistem jurnal elektronik (ejournal) dan majalah ilmiah yang menerapkan sistem daring (online) dengan persyaratan sama dengan persyaratan majalah ilmiah tercetak.

5. Memuat artikel utama tiap kali penerbitan berjumlah paling sedikit 5 (lima), selain dapat ditambahkan dengan artikel komunikasi pendek yang dibatasi paling banyak 3 (tiga) buah.

\section{METODE}

\section{Jenis Penelitian}

Dalam penelitian ini penulis menggunakan jenis penelitian kuantitatif dengan metode deskriptif. Sukmadinata (2006) menjelaskan penelitian deskriptif adalah suatu penelitianyang ditujukan untuk mendeskripsikan fenomena-fenomena yang ada, baik fenomena alamiah maupun fenomena buatan manusia. Fenomena tersebut dapat berupa bentuk,aktivitas, karakteristik, perubahan, hubungan, kesamaan, dan perbedaan antara fenomena yang satu dengan fenomena lainnya. Unit yang dianalisis adalah seluruh artikel yang terdapat pada " Jurnal Riset Akuakultur " terbitan dari tahun 2011 - 2015 yaitu sebanyak 240 artikel (Tabel 1).

Tabel 1. Unit Analisis Skala Jurnal Riset Akuakultur

\begin{tabular}{|c|c|c|c|}
\hline \multirow{2}{*}{ No. } & \multicolumn{2}{|c|}{ Jurnal Riset } & \multirow{2}{*}{ Jumlah Artikel } \\
\cline { 2 - 3 } & Tahun & Voulme & \\
\hline 1 & 2011 & 6.1 & 15 \\
\hline 2 & 2011 & 6.2 & 15 \\
\hline 3 & 2011 & 6.3 & 15 \\
\hline 4 & 2012 & 7.1 & 15 \\
\hline 5 & 2012 & 7.2 & 15 \\
\hline 6 & 2012 & 7.3 & 15 \\
\hline 7 & 2013 & 8.1 & 15 \\
\hline 8 & 2013 & 8.2 & 15 \\
\hline 9 & 2013 & 8.3 & 15 \\
\hline 10 & 2014 & 9.1 & 15 \\
\hline 11 & 2014 & 9.2 & 15 \\
\hline 12 & 2014 & 9.3 & 15 \\
\hline 13 & 2015 & 10.1 & 15 \\
\hline 14 & 2015 & 10.2 & 15 \\
\hline 15 & 2015 & 10.3 & 15 \\
\hline 16 & 2015 & 10.4 & 15 \\
\hline & Jumlah & 240 \\
\hline & & & \\
\hline
\end{tabular}

\section{Pengolahan Data}

Data yang diperoleh kemudian diolah dengan bantuan Microsoft Excel 2010. Tujuannya untuk memperoleh data awal dan memudahkan dalam pendistribusian dan pengkolaborasian data format tabel. Pengolahan data digunakan untuk menentukan:

1. Penyebaran produktif penulis selama tahun 2011-2015

2. Penyebaran Kolaborasi penulis selama 20112015

\section{Analisa Data}

Metode perhitungan yang digunakan untukmenghitung tingkat kolaborasi antar penulis adalah dengan metode Subramanyam (1983) dengan rumus:

$$
\mathrm{C}=\frac{\mathrm{Nm}}{(\mathrm{Nm}+\mathrm{Ns}}
$$

dimana:

C = tingkat kolaborasi penulis salam suatu disiplin ilmu dengan nilai berada pada interval 0 sampai dengan 1 , atau $[0,1]$

$\mathrm{Nm}=$ total hasil penelitian dari peneliti suatu disiplin ilmu pada tahun tertentu yang dilakukan secaraber kolaborasi

Ns = total hasil penelitian dari suatu disiplin ilmu pada tahun tertentu yang dilakukan secara individual

\section{Keterangan:}

1. Apabilanilai $\mathrm{C}=0$, maka dikatakan bahwa hasil penelitian pada bidang tersebut seluruhnya dilakukan secara individual(penulis tunggal)

2. Apabila nilai $C$ lebih besar dari nol dan kurang setengah $(0<\mathrm{C}<0,5)$ maka dapat dikatakan bahwa hasil penelitian yang dilakukan secara individu lebih besar dibandingkan dengan yang dilakukan secara berkolaborasi.

3. Apabila nilai $C=0,5$ maka penelitian yang dilakukan secara individual sama banyaknya dengan yang dilakukan secara berkolaborasi

4. Apabila nilai $\mathrm{C}$ lebih besar dari 0,5 dankurang dari $1(0,5<\mathrm{C}<1)$ dapat dikatakanbahwa hasil penelitian yang dilakukan secara individual lebih sedikit dibandingkan yang dilakukan secara berkolaborasi

5. Apabila nilai $\mathrm{C}=1$ maka penelitian pada bidang tersebut seluruhnya dilakukan secara berkolaborasi 


\section{HASIL DAN PEMBAHASAN}

Jurnal Riset Akuakultur adalah wadah informasi bidang akuakultur yang berupa hasilhasil riset, terbit tiga kali setahun kecuali pada tahun 2015 terbit 4 kali. Selama kurun waktu 20052010 telah memuat 240 artikel (Tabel 1).
Pada Tabel 2. Menggambarkan daftar peringkat 10 tertinggi penulis paling produktif dalam penulisan Jurnal Riset Akuakultur selama periode 5 tahun penelitian. Dalam tabel tercatat bahwa penulis yang produktif yaitu I Nyoman Radiarta (23 artikel) dan diikuti oleh Angela. Mariana Lusiastuti (18 artikel)

Tabel 2. Daftar 10 Tertinggi Peringkat Produktivitas Penulis Selama Tahun 2011-2015

\begin{tabular}{|c|c|c|c|c|c|c|c|c|}
\hline No. & Penulis & 2011 & 2012 & 2013 & 2014 & 2015 & Jumlah & Peringkat Produktivitas \\
\hline 1 & I Nyoman Radiarta & 3 & 3 & 4 & 6 & 7 & 23 & 1 \\
\hline 2 & Angela Mariana Lusiastuti & 0 & 2 & 4 & 4 & 8 & 18 & 2 \\
\hline 3 & Akhmad Mustafa & 4 & 2 & 3 & 2 & 5 & 16 & 3 \\
\hline 4 & Erlania Erlania & 1 & 1 & 3 & 5 & 6 & 16 & 3 \\
\hline 5 & Didik Ariyanto & 1 & 1 & 2 & 3 & 4 & 11 & 4 \\
\hline 6 & Enang Harris & 3 & 1 & 3 & 2 & 2 & 11 & 4 \\
\hline 7 & Haryanti & 2 & 5 & 1 & 1 & 2 & 11 & 4 \\
\hline 8 & Hasnawi & 2 & 0 & 4 & 2 & 3 & 11 & 4 \\
\hline 9 & Sari Budi Moria Sembiring & 1 & 4 & 2 & 1 & 3 & 11 & 4 \\
\hline 10 & Sukenda & 1 & 2 & 2 & 1 & 5 & 11 & 4 \\
\hline 11 & Alimuddin & 0 & 3 & 1 & 2 & 4 & 10 & 5 \\
\hline 12 & Rachmansyah & 6 & 2 & 1 & 1 & 0 & 10 & 5 \\
\hline 13 & Usman Usman & 2 & 1 & 2 & 4 & 1 & 10 & 5 \\
\hline 14 & Irma Melati & 2 & 2 & 2 & 2 & 1 & 9 & 6 \\
\hline 15 & Khairul Syahputra & 1 & 0 & 2 & 3 & 3 & 9 & 6 \\
\hline 16 & E. Primanita Hayuningtyas & 0 & 0 & 3 & 3 & 2 & 8 & 7 \\
\hline 17 & Ida Komang Wardana & 1 & 3 & 1 & 2 & 1 & 8 & 7 \\
\hline 18 & Uni Purwaningsih & 1 & 0 & 1 & 2 & 4 & 8 & 7 \\
\hline 19 & Andi Parenrengi & 2 & 0 & 3 & 2 & 0 & 7 & 8 \\
\hline 20 & Andi Tenriulo & 2 & 1 & 2 & 2 & 0 & 7 & 8 \\
\hline 21 & Bambang Iswanto & 2 & 0 & 0 & 3 & 2 & 7 & 8 \\
\hline 22 & R.R. Pudji Sinarni Dewi & 0 & 1 & 2 & 3 & 1 & 7 & 8 \\
\hline 23 & Taukhid Taukhid & 1 & 1 & 0 & 2 & 3 & 7 & 8 \\
\hline 24 & Zafril Imran Azwar & 1 & 3 & 2 & 1 & 0 & 7 & 8 \\
\hline 25 & Asda Laining & 0 & 0 & 1 & 3 & 2 & 6 & 9 \\
\hline 26 & Emma Suryati & 0 & 0 & 3 & 3 & 0 & 6 & 9 \\
\hline 27 & Estu Nugroho & 2 & 1 & 1 & 1 & 1 & 6 & 9 \\
\hline 28 & Neltje N. Palinggi & 1 & 1 & 2 & 2 & 0 & 6 & 9 \\
\hline 29 & Adang Saputra & 2 & 2 & 1 & 0 & 0 & 5 & 10 \\
\hline 30 & Dedi Jusadi & 3 & 0 & 1 & 1 & 0 & 5 & 10 \\
\hline 31 & Endang Susianingsih & 2 & 2 & 1 & 0 & 0 & 5 & 10 \\
\hline 32 & Erna Ratnawati & 0 & 1 & 3 & 1 & 0 & 5 & 10 \\
\hline 33 & Evi Tahapari & 3 & 1 & 0 & 1 & 0 & 5 & 10 \\
\hline 34 & Huria Marnis & 0 & 0 & 1 & 2 & 2 & 5 & 10 \\
\hline 35 & Imron & 1 & 0 & 0 & 2 & 2 & 5 & 10 \\
\hline 36 & Ketut Maha Setiawati & 1 & 2 & 0 & 0 & 2 & 5 & 10 \\
\hline 37 & Kukuh Nirmala & 0 & 1 & 1 & 2 & 1 & 5 & 10 \\
\hline 38 & Muliani & 2 & 2 & 0 & 0 & 1 & 5 & 10 \\
\hline 39 & Munti Yuhana & 2 & 0 & 1 & 1 & 1 & 5 & 10 \\
\hline
\end{tabular}




\begin{tabular}{|c|l|c|c|c|c|c|c|c|}
\hline No. & \multicolumn{1}{|c|}{ Penulis } & $\mathbf{2 0 1 1}$ & $\mathbf{2 0 1 2}$ & $\mathbf{2 0 1 3}$ & $\mathbf{2 0 1 4}$ & $\mathbf{2 0 1 5}$ & Jumlah & Peringkat Produktivitas \\
\hline 40 & Rezki Antoni Suhaimi & 0 & 0 & 1 & 2 & 2 & 5 & 10 \\
\hline 41 & Rommy Suprapto & 0 & 0 & 1 & 2 & 2 & 5 & 10 \\
\hline 42 & Samuel Lante & 2 & 1 & 0 & 0 & 2 & 5 & 10 \\
\hline 43 & Titin Kurniasih & 0 & 1 & 2 & 2 & 0 & 5 & 10 \\
\hline 44 & Tuti Sumiati & 0 & 1 & 1 & 0 & 3 & 5 & 10 \\
\hline 45 & Utut Widyastuti & 1 & 0 & 2 & 2 & 0 & 5 & 10 \\
\hline 46 & Wartono Hadie & 1 & 1 & 2 & 0 & 1 & 5 & 10 \\
\hline
\end{tabular}

Tabel 3. Memperlihatkan pola kepengarangan dari301 penulis dan frekuensi kolaborasi penulisan. Dari tabel ini juga terlihat terdapat 4 orang penulis dilakukan secara individual, sedangkan I Nyoman
Radiarta merupakan penulis yang paling banyak melakukan kolaborasi dengan penulis lain (23 artikel), diikuti oleh Angela Mariana Lusiastuti (18 artikel).

Tabel 3. Daftar Penyebaran Kolaborasi Penulis selama 2011-2015

\begin{tabular}{|c|c|c|c|c|c|c|}
\hline \multirow{2}{*}{ No. } & \multirow{2}{*}{ Nama Penulis } & \multicolumn{4}{|c|}{ Pola Kepengaran Penulis } & \multirow{2}{*}{ Frekuensi Kolaborasi Penulisan } \\
\hline & & 1 & 2 & $>2$ & Jumlah Artikel & \\
\hline 1 & I Nyoman Radiarta & 0 & 14 & 9 & 23 & 23 \\
\hline 2 & Angela Mariana Lusiastuti & 1 & 2 & 15 & 18 & 17 \\
\hline 3 & Akhmad Mustafa & 0 & 6 & 10 & 16 & 16 \\
\hline 4 & Erlania & 0 & 7 & 9 & 16 & 16 \\
\hline 5 & Didik Ariyanto, & 0 & 7 & 4 & 11 & 11 \\
\hline 6 & Enang Harris & 0 & 0 & 11 & 11 & 11 \\
\hline 7 & Haryanti & 0 & 3 & 8 & 11 & 11 \\
\hline 8 & Hasnawi & 0 & 3 & 8 & 11 & 11 \\
\hline 9 & Sari Budi Moria Sembiring & 0 & 5 & 6 & 11 & 11 \\
\hline 10 & Sukenda Sukenda & 0 & 0 & 11 & 11 & 11 \\
\hline 11 & Alimuddin & 0 & 0 & 10 & 10 & 10 \\
\hline 12 & Rachmansyah Rachmansyah & 0 & 4 & 6 & 10 & 10 \\
\hline 13 & Usman & 0 & 5 & 5 & 10 & 10 \\
\hline 14 & Irma Melati & 0 & 2 & 7 & 9 & 9 \\
\hline 15 & Khairul Syahputra & 0 & 3 & 6 & 9 & 9 \\
\hline 16 & Erma Primanita Hayuningtyas & 0 & 2 & 6 & 8 & 8 \\
\hline 17 & Ida Komang Wardana & 0 & 2 & 6 & 8 & 8 \\
\hline 18 & Uni Purwaningsih & 0 & 3 & 5 & 8 & 8 \\
\hline 19 & Zafril Imran Azwar & 0 & 2 & 6 & 8 & 8 \\
\hline 20 & Andi Parenrengi & 0 & 2 & 5 & 7 & 7 \\
\hline 21 & Andi Tenriulo & 0 & 0 & 7 & 7 & 7 \\
\hline 22 & Bambang Iswanto & 0 & 4 & 3 & 7 & 7 \\
\hline 23 & Nurhidayat & 0 & 3 & 4 & 7 & 7 \\
\hline 24 & R.R. Pudji Sinarni Dewi & 0 & 4 & 3 & 7 & 7 \\
\hline 25 & Taukhid Taukhid & 0 & 3 & 4 & 7 & 7 \\
\hline 26 & Asda Laining & 0 & 2 & 4 & 6 & 6 \\
\hline 27 & Desy Sugiani & 0 & 4 & 2 & 6 & 6 \\
\hline 28 & Emma Suryati & 0 & 3 & 3 & 6 & 6 \\
\hline 29 & Estu Nugroho & 0 & 4 & 2 & 6 & 6 \\
\hline 30 & Neltje Nobertine Palinggi & 0 & 2 & 4 & 6 & 6 \\
\hline 31 & Adang Saputra & 0 & 1 & 4 & 5 & 5 \\
\hline
\end{tabular}




\begin{tabular}{|c|c|c|c|c|c|c|}
\hline \multirow{2}{*}{ No. } & \multirow{2}{*}{ Nama Penulis } & \multicolumn{4}{|c|}{ Pola Kepengaran Penulis } & \multirow{2}{*}{ Frekuensi Kolaborasi Penulisan } \\
\hline & & 1 & 2 & $>2$ & Jumlah Artikel & \\
\hline 32 & Dedi Jusadi & 0 & 0 & 5 & 5 & 5 \\
\hline 33 & Endang Susianingsih & 0 & 1 & 4 & 5 & 5 \\
\hline 34 & Erna Ratnawati & 0 & 1 & 4 & 5 & 5 \\
\hline 35 & Evi Tahapari & 0 & 1 & 4 & 5 & 5 \\
\hline 36 & Huria Marnis & 0 & 2 & 3 & 5 & 5 \\
\hline 37 & Imron & 0 & 0 & 5 & 5 & 5 \\
\hline 38 & Kukuh Nirmala & 0 & 0 & 5 & 5 & 5 \\
\hline 39 & Muliani & 0 & 5 & 0 & 5 & 5 \\
\hline 40 & Mulyasari Mulyasari & 0 & 1 & 4 & 5 & 5 \\
\hline 41 & Munti Yuhana & 0 & 0 & 5 & 5 & 5 \\
\hline 42 & Rezki Antoni Suhaimi & 0 & 1 & 4 & 5 & 5 \\
\hline 43 & Rommy Suprapto & 0 & 0 & 5 & 5 & 5 \\
\hline 44 & Samuel Lante & 0 & 3 & 2 & 5 & 5 \\
\hline 45 & Sularto & 0 & 2 & 3 & 5 & 5 \\
\hline 46 & Titin Kurniasih & 0 & 4 & 1 & 5 & 5 \\
\hline 47 & Tuti Sumiati & 0 & 2 & 3 & 5 & 5 \\
\hline 48 & Utut Widyastuti & 0 & 0 & 5 & 5 & 5 \\
\hline 49 & Wartono Hadie & 0 & 3 & 2 & 5 & 5 \\
\hline 50 & Adam Robisalmi, & 0 & 2 & 2 & 4 & 4 \\
\hline 51 & Agus Oman Sudrajat, & 0 & 0 & 4 & 4 & 4 \\
\hline 52 & Anang Hari Kristanto & 0 & 0 & 4 & 4 & 4 \\
\hline 53 & Daniar Kusumawati, & 0 & 3 & 1 & 4 & 4 \\
\hline 54 & Eddy Supriyono & 0 & 0 & 4 & 4 & 4 \\
\hline 55 & Gusti Ngurah Permana, & 0 & 3 & 1 & 4 & 4 \\
\hline 56 & I Gusti Ngurah Permana, & 0 & 0 & 4 & 4 & 4 \\
\hline 57 & Ibnu Rusdi, & 0 & 0 & 4 & 4 & 4 \\
\hline 58 & Jhon Harianto Hutapea, & 0 & 0 & 4 & 4 & 4 \\
\hline 59 & Jojo Subagja, & 0 & 2 & 2 & 4 & 4 \\
\hline 60 & Ketut Maha Setiawati, & 0 & 2 & 2 & 4 & 4 \\
\hline 61 & Ketut Suwirya, & 0 & 2 & 2 & 4 & 4 \\
\hline 62 & Mudian Paena & 0 & 0 & 4 & 4 & 4 \\
\hline 63 & Nurbaya Nurbaya, & 0 & 0 & 4 & 4 & 4 \\
\hline 64 & Ofri Johan, & 0 & 3 & 1 & 4 & 4 \\
\hline 65 & Otong Zenal Arifin & 0 & 0 & 4 & 4 & 4 \\
\hline 66 & Priadi Setyawan, & 0 & 1 & 3 & 4 & 4 \\
\hline 67 & Rudhy Gustiano, & 0 & 1 & 3 & 4 & 4 \\
\hline 68 & Suharsono & 0 & 0 & 4 & 4 & 4 \\
\hline 69 & Utojo & 0 & 4 & 0 & 4 & 4 \\
\hline 70 & Wawan Andriyanto, & 0 & 1 & 3 & 4 & 4 \\
\hline 71 & Abbas Sommeng, & 0 & 0 & 3 & 3 & 3 \\
\hline 72 & Abdul Karim Gaffar & 0 & 0 & 3 & 3 & 3 \\
\hline 73 & Agustin Indrawati, & 0 & 0 & 3 & 3 & 3 \\
\hline 74 & Ahmad Muzaki & 0 & 0 & 3 & 3 & 3 \\
\hline 75 & Anjang Bangun Prasetio, & 0 & 1 & 2 & 3 & 3 \\
\hline 76 & Bambang Gunadi, & 0 & 1 & 2 & 3 & 3 \\
\hline 77 & Brata Pantjara, & 0 & 2 & 1 & 3 & 3 \\
\hline
\end{tabular}




\begin{tabular}{|c|c|c|c|c|c|c|}
\hline \multirow{2}{*}{ No. } & \multirow{2}{*}{ Nama Penulis } & \multicolumn{4}{|c|}{ Pola Kepengaran Penulis } & \multirow{2}{*}{ Frekuensi Kolaborasi Penulisan } \\
\hline & & 1 & 2 & $>2$ & Jumlah Artikel & \\
\hline 78 & Eni Kusrini, & 0 & 0 & 3 & 3 & 3 \\
\hline 79 & Fachrudin Fachrudin, & 0 & 0 & 3 & 3 & 3 \\
\hline 80 & Hidayat Suryanto Suwoyo & 0 & 0 & 3 & 3 & 3 \\
\hline 81 & I Wayan Subamia, & 0 & 1 & 2 & 3 & 3 \\
\hline 82 & Irin Iriana Kusmini, & 0 & 1 & 2 & 3 & 3 \\
\hline 83 & Iskandariah Iskandariah, & 0 & 2 & 1 & 3 & 3 \\
\hline 84 & Isti Koesharyani, & 0 & 2 & 1 & 3 & 3 \\
\hline 85 & Kamaruddin Kamaruddin & 0 & 0 & 3 & 3 & 3 \\
\hline 86 & Ketut Mahardika & 0 & 0 & 3 & 3 & 3 \\
\hline 87 & Ketut Sugama & 0 & 0 & 3 & 3 & 3 \\
\hline 88 & Komar Sumantadinata & 0 & 0 & 3 & 3 & 3 \\
\hline 89 & Lila Gardenia, & 0 & 1 & 2 & 3 & 3 \\
\hline 90 & Makmur Makmur, & 0 & 0 & 3 & 3 & 3 \\
\hline 91 & Muhammad Marzuqi, & 0 & 2 & 1 & 3 & 3 \\
\hline 92 & Muhammad Zairin Junior & 0 & 0 & 3 & 3 & 3 \\
\hline 93 & Mustafa, & 0 & 0 & 3 & 3 & 3 \\
\hline 94 & Ni Wayan Widya Astuti & 0 & 0 & 3 & 3 & 3 \\
\hline 95 & Nina Meilisza, & 0 & 0 & 3 & 3 & 3 \\
\hline 96 & Nunuk Listiyowati, & 0 & 1 & 2 & 3 & 3 \\
\hline 97 & Nur Bambang Priyo Utomo & 0 & 0 & 3 & 3 & 3 \\
\hline 98 & Ruby Vidia Kusumah, & 0 & 2 & 1 & 3 & 3 \\
\hline 99 & Siti Murniasih & 0 & 0 & 3 & 3 & 3 \\
\hline 100 & Siti Subandiyah, & 0 & 2 & 1 & 3 & 3 \\
\hline 101 & Syarifuddin Tonnek & 0 & 0 & 3 & 3 & 3 \\
\hline 102 & Tatik Mufidah, & 0 & 1 & 2 & 3 & 3 \\
\hline 103 & Aan Fibro Widodo, & 0 & 2 & 0 & 2 & 2 \\
\hline 104 & Agus Priyadi, & 0 & 1 & 1 & 2 & 2 \\
\hline 105 & Andi Indra Jaya Asaad, & 0 & 0 & 2 & 2 & 2 \\
\hline 106 & Ani Widiyati, & 0 & 1 & 1 & 2 & 2 \\
\hline 107 & Asep Permana & 0 & 0 & 2 & 2 & 2 \\
\hline 108 & Asep Sopian & 0 & 0 & 2 & 2 & 2 \\
\hline 109 & Bambang Priono & 0 & 0 & 2 & 2 & 2 \\
\hline 110 & Bambang Susanto, & 0 & 1 & 1 & 2 & 2 \\
\hline 111 & Bejo Slamet, & 0 & 1 & 1 & 2 & 2 \\
\hline 112 & Bunga Rante Tampangallo, & 0 & 0 & 2 & 2 & 2 \\
\hline 113 & Dietriech G. Bengen & 0 & 0 & 2 & 2 & 2 \\
\hline 114 & Dinar Tri Soelistyowati & 0 & 0 & 2 & 2 & 2 \\
\hline 115 & Eri Setiadi & 0 & 0 & 2 & 2 & 2 \\
\hline 116 & Hambali Supriyadi & 0 & 0 & 2 & 2 & 2 \\
\hline 117 & Herlinah Herlinah, & 0 & 1 & 1 & 2 & 2 \\
\hline 118 & Hirmawan Tirta Yudha & 0 & 0 & 2 & 2 & 2 \\
\hline 119 & Ibnu Dwi Buwono, & 0 & 2 & 0 & 2 & 2 \\
\hline 120 & idil Ardi & 0 & 0 & 2 & 2 & 2 \\
\hline 121 & Ikhsan Khasani, & 0 & 2 & 0 & 2 & 2 \\
\hline 122 & Ince Ayu Khairana Kadriah, & 0 & 2 & 0 & 2 & 2 \\
\hline 123 & Joni Haryadi & 0 & 0 & 2 & 2 & 2 \\
\hline
\end{tabular}




\begin{tabular}{|c|c|c|c|c|c|c|}
\hline \multirow{2}{*}{ No. } & \multirow{2}{*}{ Nama Penulis } & \multicolumn{4}{|c|}{ Pola Kepengaran Penulis } & \multirow{2}{*}{ Frekuensi Kolaborasi Penulisan } \\
\hline & & 1 & 2 & $>2$ & Jumlah Artikel & \\
\hline 124 & Kamariah & 0 & 0 & 2 & 2 & 2 \\
\hline 125 & Koko Kurniawan & 0 & 0 & 2 & 2 & 2 \\
\hline 126 & Kurniasih Kurniasih & 0 & 0 & 2 & 2 & 2 \\
\hline 127 & Lamanto Lamanto & 0 & 0 & 2 & 2 & 2 \\
\hline 128 & Lili Sholichah, & 0 & 2 & 0 & 2 & 2 \\
\hline 129 & Mas Tri Djoko Sunarno & 0 & 0 & 2 & 2 & 2 \\
\hline 130 & Mun Imah Madeali, & 0 & 1 & 1 & 2 & 2 \\
\hline 131 & Muslimin Muslimin, & 0 & 1 & 1 & 2 & 2 \\
\hline 132 & Nono Carsono, & 0 & 0 & 2 & 2 & 2 \\
\hline 133 & Odang Carman & 0 & 0 & 2 & 2 & 2 \\
\hline 134 & Retno Andamari & 0 & 0 & 2 & 2 & 2 \\
\hline 135 & Rina Hirnawati, & 0 & 0 & 2 & 2 & 2 \\
\hline 136 & Ristanti Frinra Daud, & 0 & 1 & 1 & 2 & 2 \\
\hline 137 & S.R. Hesti Mulyaningrum, & 0 & 2 & 0 & 2 & 2 \\
\hline 138 & Sri Nuryati & 0 & 0 & 2 & 2 & 2 \\
\hline 139 & Sudewi & 0 & 0 & 2 & 2 & 2 \\
\hline 140 & Sukarman Sukarman, & 0 & 1 & 1 & 2 & 2 \\
\hline 141 & Suko Ismi, & 0 & 1 & 1 & 2 & 2 \\
\hline 142 & Tarunamulia Tarunamulia, & 0 & 2 & 0 & 2 & 2 \\
\hline 143 & Tatam Sutarmat, & 0 & 1 & 1 & 2 & 2 \\
\hline 144 & Titiek Aslianti, & 0 & 1 & 1 & 2 & 2 \\
\hline 145 & Tony Setiadharma & 0 & 0 & 2 & 2 & 2 \\
\hline 146 & Tutik Kadarini, & 0 & 2 & 0 & 2 & 2 \\
\hline 147 & Vitas Atmadi Prakoso, & 0 & 0 & 2 & 2 & 2 \\
\hline 148 & Widanarni Widanarni, & 0 & 0 & 2 & 2 & 2 \\
\hline 149 & Abdul Mansyur, & 0 & 1 & 0 & 1 & 1 \\
\hline 150 & Ade Dwi Sasanti & 0 & 0 & 1 & 1 & 1 \\
\hline 151 & Ade Nurdin, & 0 & 1 & 0 & 1 & 1 \\
\hline 152 & Aditiya Nugraha & 0 & 0 & 1 & 1 & 1 \\
\hline 153 & Admi Athirah, & 0 & 0 & 1 & 1 & 1 \\
\hline 154 & Afifah Afifah & 0 & 0 & 1 & 1 & 1 \\
\hline 155 & Afifah Nasukha & 0 & 0 & 1 & 1 & 1 \\
\hline 156 & Agung Cahyo Setyawan & 0 & 1 & 0 & 1 & 1 \\
\hline 157 & Agus Irianto & 0 & 1 & 0 & 1 & 1 \\
\hline 158 & Agus Nawang & 0 & 0 & 1 & 1 & 1 \\
\hline 159 & Agus Priyono & 0 & 0 & 1 & 1 & 1 \\
\hline 160 & Agus Sunarto & 0 & 0 & 1 & 1 & 1 \\
\hline 161 & Ahmad Fauzan & 0 & 0 & 1 & 1 & 1 \\
\hline 162 & Amrullah Amrullah & 0 & 1 & 0 & 1 & 1 \\
\hline 163 & Apri Imam Supii & 0 & 0 & 1 & 1 & 1 \\
\hline 164 & Arifuddin Tompo & 0 & 0 & 1 & 1 & 1 \\
\hline 165 & Armen Nainggolan & 0 & 1 & 0 & 1 & 1 \\
\hline 166 & Asfie Maidie & 0 & 0 & 1 & 1 & 1 \\
\hline 167 & Asmi Citra Malina & 0 & 0 & 1 & 1 & 1 \\
\hline 168 & Azis Azis & 0 & 1 & 0 & 1 & 1 \\
\hline 169 & Azrita Azrita & 0 & 1 & 0 & 1 & 1 \\
\hline
\end{tabular}




\begin{tabular}{|c|c|c|c|c|c|c|}
\hline \multirow{2}{*}{ No. } & \multirow{2}{*}{ Nama Penulis } & \multicolumn{4}{|c|}{ Pola Kepengaran Penulis } & \multirow{2}{*}{ Frekuensi Kolaborasi Penulisan } \\
\hline & & 1 & 2 & $>2$ & Jumlah Artikel & \\
\hline 170 & Badraeni Badraeni & 0 & 0 & 1 & 1 & 1 \\
\hline 171 & Bagus Wasito & 0 & 0 & 1 & 1 & 1 \\
\hline 172 & Budiyanto Budiyanto & 0 & 0 & 1 & 1 & 1 \\
\hline 173 & Chumaidi Chumaidi & 0 & 1 & 0 & 1 & 1 \\
\hline 174 & D. Djokosetyanto & 0 & 0 & 1 & 1 & 1 \\
\hline 175 & Dahelmi Dahelmi & 0 & 0 & 1 & 1 & 1 \\
\hline 176 & Daniel Limbong & 0 & 0 & 1 & 1 & 1 \\
\hline 177 & Deni Radona & 0 & 1 & 0 & 1 & 1 \\
\hline 178 & Didik T. Subekti & 0 & 0 & 1 & 1 & 1 \\
\hline 179 & Didit Dewanto, & 0 & 0 & 1 & 1 & 1 \\
\hline 180 & Dinamella Wahjuningrum & 0 & 0 & 1 & 1 & 1 \\
\hline 181 & Dody Dh Trijuno & 0 & 0 & 1 & 1 & 1 \\
\hline 182 & Dwijo Priyanto, & 0 & 0 & 1 & 1 & 1 \\
\hline 183 & Eka Nurdian, & 0 & 0 & 1 & 1 & 1 \\
\hline 184 & Erfan Andi Hendradjat & 0 & 0 & 1 & 1 & 1 \\
\hline 185 & Erni Kristina Pambayuningrum & 0 & 0 & 1 & 1 & 1 \\
\hline 186 & Erwiantono Erwiantono, & 0 & 0 & 1 & 1 & 1 \\
\hline 187 & Erwin N. Fahlefi & 0 & 0 & 1 & 1 & 1 \\
\hline 188 & Fachriyan Hasmi Pasaribu & 0 & 0 & 1 & 1 & 1 \\
\hline 189 & Farah Diana, & 0 & 1 & 0 & 1 & 1 \\
\hline 190 & Ferdinand Hukama Taqwa, & 0 & 1 & 0 & 1 & 1 \\
\hline 191 & Fitri Husnul Khotimah, & 0 & 0 & 1 & 1 & 1 \\
\hline 192 & Gavin Patridge & 0 & 0 & 1 & 1 & 1 \\
\hline 193 & Gede S. Sumiarsa, & 0 & 1 & 0 & 1 & 1 \\
\hline 194 & Gigih Setia Wibawa & 0 & 0 & 1 & 1 & 1 \\
\hline 195 & Gleny Hasan Huwoyon, & 0 & 0 & 1 & 1 & 1 \\
\hline 196 & Gunarto Gunarto, & 0 & 1 & 0 & 1 & 1 \\
\hline 197 & Hafrijal Syandri & 0 & 0 & 1 & 1 & 1 \\
\hline 198 & Happy Nursyam & 0 & 0 & 1 & 1 & 1 \\
\hline 199 & Hasnawi Hasnawi & 0 & 0 & 1 & 1 & 1 \\
\hline 200 & Hatim Albasri & 0 & 0 & 1 & 1 & 1 \\
\hline 201 & Heri Wibowo & 0 & 0 & 1 & 1 & 1 \\
\hline 202 & Hery Sulistyo & 0 & 0 & 1 & 1 & 1 \\
\hline 203 & Hessy Novita & 0 & 1 & 0 & 1 & 1 \\
\hline 204 & I.W. Teguh Wibawan & 0 & 0 & 1 & 1 & 1 \\
\hline 205 & Ika Nurlaela & 0 & 0 & 1 & 1 & 1 \\
\hline 206 & Imam Taufik & 0 & 1 & 0 & 1 & 1 \\
\hline 207 & Iman Rusmana & 0 & 0 & 1 & 1 & 1 \\
\hline 208 & Indira Fitriliyani & 0 & 0 & 1 & 1 & 1 \\
\hline 209 & Ing Mokoginta & 0 & 0 & 1 & 1 & 1 \\
\hline 210 & Inneke F.M. Rumengan & 0 & 1 & 0 & 1 & 1 \\
\hline 211 & Iswari Ratna Astuti & 0 & 1 & 0 & 1 & 1 \\
\hline 212 & Jadmiko Darmawan & 0 & 0 & 1 & 1 & 1 \\
\hline 213 & Jatnika Jatnika & 0 & 0 & 1 & 1 & 1 \\
\hline 214 & Jesmond Sammut & 0 & 0 & 1 & 1 & 1 \\
\hline 215 & Joko Prastowo & 0 & 0 & 1 & 1 & 1 \\
\hline
\end{tabular}




\begin{tabular}{|c|c|c|c|c|c|c|}
\hline \multirow{2}{*}{ No. } & \multirow{2}{*}{ Nama Penulis } & \multicolumn{4}{|c|}{ Pola Kepengaran Penulis } & \multirow{2}{*}{ Frekuensi Kolaborasi Penulisan } \\
\hline & & 1 & 2 & $>2$ & Jumlah Artikel & \\
\hline 216 & Kamaluddin Mahfudz & 0 & 0 & 1 & 1 & 1 \\
\hline 217 & Khumaira Puspasari & 0 & 0 & 1 & 1 & 1 \\
\hline 218 & Kusdiarti Kusdiarti & 0 & 0 & 1 & 1 & 1 \\
\hline 219 & Lalu Mayadi & 0 & 0 & 1 & 1 & 1 \\
\hline 220 & Lida Puspaningtyas & 0 & 0 & 1 & 1 & 1 \\
\hline 221 & Lideman Lideman & 0 & 1 & 0 & 1 & 1 \\
\hline 222 & Lies Emmawati Hadie & 0 & 1 & 0 & 1 & 1 \\
\hline 223 & Linda Sugiarti & 0 & 0 & 1 & 1 & 1 \\
\hline 224 & M. Agus Suprayudi & 0 & 0 & 1 & 1 & 1 \\
\hline 225 & $\begin{array}{l}\text { M. Hunaina Fariduddin Ath- } \\
\text { thar }\end{array}$ & 0 & 1 & 0 & 1 & 1 \\
\hline 226 & $\begin{array}{l}\text { M. Hunaina Fariduddin Ath- } \\
\text { thar }\end{array}$ & 0 & 0 & 1 & 1 & 1 \\
\hline 227 & Maria Bintang & 0 & 0 & 1 & 1 & 1 \\
\hline 228 & Markus Mangampa & 0 & 0 & 1 & 1 & 1 \\
\hline 229 & Mas Bayu Syamsunarno & 0 & 1 & 0 & 1 & 1 \\
\hline 230 & Michael A. Rimmer & 0 & 0 & 1 & 1 & 1 \\
\hline 231 & Mochamad Bajar & 0 & 0 & 1 & 1 & 1 \\
\hline 232 & Mochamad Nurdin, & 0 & 1 & 0 & 1 & 1 \\
\hline 233 & Mochammad Zamroni, & 0 & 0 & 1 & 1 & 1 \\
\hline 234 & Mohammad Ali Syahdan & 0 & 0 & 1 & 1 & 1 \\
\hline 235 & Mufti P. Patria & 0 & 0 & 1 & 1 & 1 \\
\hline 236 & Muhammad Husni Amarullah & 0 & 0 & 1 & 1 & 1 \\
\hline 237 & Muhammad Muhammad & 0 & 1 & 0 & 1 & 1 \\
\hline 238 & Muhammad Yamin Paada & 0 & 0 & 1 & 1 & 1 \\
\hline 239 & Muharijadi Atmomarsono & 0 & 0 & 1 & 1 & 1 \\
\hline 240 & Narita Syawalia & 0 & 0 & 1 & 1 & 1 \\
\hline 241 & Neviaty P. Zamani & 0 & 0 & 1 & 1 & 1 \\
\hline 242 & Niken T.M. Pratiwi & 0 & 0 & 1 & 1 & 1 \\
\hline 243 & Ningrum Suhenda & 0 & 0 & 1 & 1 & 1 \\
\hline 244 & Noor Bimo Adhiyudanto & 0 & 0 & 1 & 1 & 1 \\
\hline 245 & Novi Megawati & 0 & 0 & 1 & 1 & 1 \\
\hline 246 & Nunak Nafiqoh & 0 & 0 & 1 & 1 & 1 \\
\hline 247 & Nyoman Adiasmara Giri & 0 & 1 & 0 & 1 & 1 \\
\hline 248 & O.D. Subakti Hasan & 0 & 1 & 0 & 1 & 1 \\
\hline 249 & Philip Teguh Imanto & 0 & 0 & 1 & 1 & 1 \\
\hline 250 & Qoriah Saleha & 0 & 0 & 1 & 1 & 1 \\
\hline 251 & Rani Hafsaridewi & 0 & 0 & 1 & 1 & 1 \\
\hline 252 & Rarastoeti Pratiwi & 0 & 0 & 1 & 1 & 1 \\
\hline 253 & Rasidi Rasidi & 0 & 0 & 1 & 1 & 1 \\
\hline 254 & Ratu Siti Aliah & 0 & 0 & 1 & 1 & 1 \\
\hline 255 & Regina Melianawati & 0 & 0 & 1 & 1 & 1 \\
\hline 256 & Rendy Ginanjar & 0 & 0 & 1 & 1 & 1 \\
\hline 257 & Reza Samsudin & 0 & 1 & 0 & 1 & 1 \\
\hline 258 & Rina Astuti & 0 & 0 & 1 & 1 & 1 \\
\hline 259 & Rinny Modaso & 0 & 0 & 1 & 1 & 1 \\
\hline
\end{tabular}




\begin{tabular}{|c|c|c|c|c|c|c|}
\hline \multirow{2}{*}{ No. } & \multirow{2}{*}{ Nama Penulis } & \multicolumn{4}{|c|}{ Pola Kepengaran Penulis } & \multirow{2}{*}{ Frekuensi Kolaborasi Penulisan } \\
\hline & & 1 & 2 & $>2$ & Jumlah Artikel & \\
\hline 260 & Rita Febrianti & 0 & 1 & 0 & 1 & 1 \\
\hline 261 & Rohama Daud & 0 & 0 & 1 & 1 & 1 \\
\hline 262 & Rusman Rusman & 0 & 0 & 1 & 1 & 1 \\
\hline 263 & Rustadi Rustadi & 0 & 0 & 1 & 1 & 1 \\
\hline 264 & Ruzkiah Asaf & 0 & 1 & 0 & 1 & 1 \\
\hline 265 & S. Permana & 0 & 0 & 1 & 1 & 1 \\
\hline 266 & Sabara Putra & 0 & 0 & 1 & 1 & 1 \\
\hline 267 & Saepudin & 0 & 0 & 1 & 1 & 1 \\
\hline 268 & Sari Dwi Maryanti & 0 & 0 & 1 & 1 & 1 \\
\hline 269 & Sawung Cindelaras & 0 & 0 & 1 & 1 & 1 \\
\hline 270 & Sigit Budileksono & 0 & 0 & 1 & 1 & 1 \\
\hline 271 & Siti Fatimah & 0 & 1 & 0 & 1 & 1 \\
\hline 272 & Siti Narwiyani & 0 & 1 & 0 & 1 & 1 \\
\hline 273 & Siti Subandiyah & 0 & 0 & 1 & 1 & 1 \\
\hline 274 & Siti Zuhriyyah Musthofa, S & 0 & 0 & 1 & 1 & 1 \\
\hline 275 & Sophia Lasma Sagala & 0 & 0 & 1 & 1 & 1 \\
\hline 276 & Sri Murtini & 0 & 0 & 1 & 1 & 1 \\
\hline 277 & Sri Sundari & 0 & 0 & 1 & 1 & 1 \\
\hline 278 & Sumoharjo & 0 & 1 & 0 & 1 & 1 \\
\hline 279 & Sunaryo & 0 & 0 & 1 & 1 & 1 \\
\hline 280 & Susila & 0 & 0 & 1 & 1 & 1 \\
\hline 281 & Sutanti & 0 & 0 & 1 & 1 & 1 \\
\hline 282 & Suwardi Tahe & 0 & 1 & 0 & 1 & 1 \\
\hline 283 & Syaifullah Syaifullah & 0 & 0 & 1 & 1 & 1 \\
\hline 284 & Syamsu Alam Ali & 0 & 0 & 1 & 1 & 1 \\
\hline 285 & Tri Heru Prihadi & 0 & 0 & 1 & 1 & 1 \\
\hline 286 & Turmuzi Tammi & 0 & 1 & 0 & 1 & 1 \\
\hline 287 & Ulia Fajriah & 0 & 1 & 0 & 1 & 1 \\
\hline 288 & Wahyulia Cahyanti & 0 & 0 & 1 & 1 & 1 \\
\hline 289 & Windarti Windarti & 0 & 0 & 1 & 1 & 1 \\
\hline 290 & Wiwien Mukti Andriyani & 0 & 1 & 0 & 1 & 1 \\
\hline 291 & Wiwin Kusuma Atmaja Putra & 0 & 1 & 0 & 1 & 1 \\
\hline 292 & Yani Aryati & 0 & 0 & 1 & 1 & 1 \\
\hline 293 & Yasmina Nirmala Asih & 0 & 0 & 1 & 1 & 1 \\
\hline 294 & Yenny Risjani & 0 & 0 & 1 & 1 & 1 \\
\hline 295 & Yogi Himawan & 0 & 0 & 1 & 1 & 1 \\
\hline 296 & Yuke Eliyani & 0 & 1 & 0 & 1 & 1 \\
\hline 297 & Yuniar Mulyani & 0 & 0 & 1 & 1 & 1 \\
\hline 298 & Zulkifli Zulkifli & 0 & 0 & 1 & 1 & 1 \\
\hline 299 & Irsyaphiani Insan & 1 & 0 & 0 & 1 & 0 \\
\hline 300 & Isriansyah Isriansyah & 1 & 0 & 0 & 1 & 0 \\
\hline 301 & Wahyu Pamungkas & 1 & 0 & 0 & 1 & 0 \\
\hline
\end{tabular}


Tabel 4. Daftar Perbandingan Penulis Peringkat Produktivitas dan Peringkat Kolaborasi Jurnal Riset Akuakultur 2015-2015

\begin{tabular}{|c|c|c|c|c|}
\hline No. & Nama Penulis & NS & NM & C \\
\hline 1 & Aan Fibro Widodo, & 0 & 2 & 1,000 \\
\hline 2 & Abbas Sommeng, & 0 & 3 & 1,000 \\
\hline 3 & Abdul Karim Gaffar & 0 & 3 & 1,000 \\
\hline 4 & Abdul Mansyur, & 0 & 1 & 1,000 \\
\hline 5 & Adam Robisalmi, & 0 & 4 & 1,000 \\
\hline 6 & Adang Saputra & 0 & 5 & 1,000 \\
\hline 7 & Ade Dwi Sasanti & 0 & 1 & 1,000 \\
\hline 8 & Ade Nurdin, & 0 & 1 & 1,000 \\
\hline 9 & Aditiya Nugraha & 0 & 1 & 1,000 \\
\hline 10 & Admi Athirah, & 0 & 1 & 1,000 \\
\hline 11 & Afifah Afifah & 0 & 1 & 1,000 \\
\hline 12 & Afifah Nasukha & 0 & 1 & 1,000 \\
\hline 13 & Agung Cahyo Setyawan & 0 & 1 & 1,000 \\
\hline 14 & Agus Irianto & 0 & 1 & 1,000 \\
\hline 15 & Agus Nawang & 0 & 1 & 1,000 \\
\hline 16 & Agus Oman Sudrajat, & 0 & 4 & 1,000 \\
\hline 17 & Agus Priyadi, & 0 & 2 & 1,000 \\
\hline 18 & Agus Priyono & 0 & 1 & 1,000 \\
\hline 19 & Agus Sunarto & 0 & 1 & 1,000 \\
\hline 20 & Agustin Indrawati, & 0 & 3 & 1,000 \\
\hline 21 & Ahmad Fauzan & 0 & 1 & 1,000 \\
\hline 22 & Ahmad Muzaki & 0 & 3 & 1,000 \\
\hline 23 & Akhmad Mustafa & 0 & 16 & 1,000 \\
\hline 24 & Alimuddin & 0 & 10 & 1,000 \\
\hline 25 & Amrullah Amrullah & 0 & 1 & 1,000 \\
\hline 26 & Anang Hari Kristanto & 0 & 4 & 1,000 \\
\hline 27 & Andi Indra Jaya Asaad, & 0 & 2 & 1,000 \\
\hline 28 & Andi Parenrengi & 0 & 7 & 1,000 \\
\hline 29 & Andi Tenriulo & 0 & 7 & 1,000 \\
\hline 30 & Ani Widiyati, & 0 & 2 & 1,000 \\
\hline 31 & Anjang Bangun Prasetio, & 0 & 3 & 1,000 \\
\hline 32 & Apri Imam Supii & 0 & 1 & 1,000 \\
\hline 33 & Arifuddin Tompo & 0 & 1 & 1,000 \\
\hline 34 & Armen Nainggolan & 0 & 1 & 1,000 \\
\hline 35 & Asda Laining & 0 & 6 & 1,000 \\
\hline 36 & Asep Permana & 0 & 2 & 1,000 \\
\hline 37 & Asep Sopian & 0 & 2 & 1,000 \\
\hline 38 & Asfie Maidie & 0 & 1 & 1,000 \\
\hline 39 & Asmi Citra Malina & 0 & 1 & 1,000 \\
\hline 40 & Azis Azis & 0 & 1 & 1,000 \\
\hline 41 & Azrita Azrita & 0 & 1 & 1,000 \\
\hline 42 & Badraeni Badraeni & 0 & 1 & 1,000 \\
\hline 43 & Bagus Wasito & 0 & 1 & 1,000 \\
\hline 44 & Bambang Gunadi, & 0 & 3 & 1,000 \\
\hline 45 & Bambang Iswanto & 0 & 7 & 1,000 \\
\hline
\end{tabular}

\begin{tabular}{|c|c|c|c|c|}
\hline No. & Nama Penulis & NS & NM & C \\
\hline 46 & Bambang Priono & 0 & 2 & 1,000 \\
\hline 47 & Bambang Susanto, & 0 & 2 & 1,000 \\
\hline 48 & Bejo Slamet, & 0 & 2 & 1,000 \\
\hline 49 & Brata Pantjara, & 0 & 3 & 1,000 \\
\hline 50 & Budiyanto Budiyanto & 0 & 1 & 1,000 \\
\hline 51 & $\begin{array}{l}\text { Bunga Rante } \\
\text { Tampangallo, }\end{array}$ & 0 & 2 & 1,000 \\
\hline 52 & Chumaidi Chumaidi & 0 & 1 & 1,000 \\
\hline 53 & D. Djokosetyanto & 0 & 1 & 1,000 \\
\hline 54 & Dahelmi Dahelmi & 0 & 1 & 1,000 \\
\hline 55 & Daniar Kusumawati, & 0 & 4 & 1,000 \\
\hline 56 & Daniel Limbong & 0 & 1 & 1,000 \\
\hline 57 & Dedi Jusadi & 0 & 5 & 1,000 \\
\hline 58 & Deni Radona & 0 & 1 & 1,000 \\
\hline 59 & Desy Sugiani & 0 & 6 & 1,000 \\
\hline 60 & Didik Ariyanto, & 0 & 11 & 1,000 \\
\hline 61 & Didik T. Subekti & 0 & 1 & 1,000 \\
\hline 62 & Didit Dewanto, & 0 & 1 & 1,000 \\
\hline 63 & Dietriech G. Bengen & 0 & 2 & 1,000 \\
\hline 64 & Dinamella Wahjuningrum & 0 & 1 & 1,000 \\
\hline 65 & Dinar Tri Soelistyowati & 0 & 2 & 1,000 \\
\hline 66 & Dody Dh Trijuno & 0 & 1 & 1,000 \\
\hline 67 & Dwijo Priyanto, & 0 & 1 & 1,000 \\
\hline 68 & Eddy Supriyono & 0 & 4 & 1,000 \\
\hline 69 & Eka Nurdian, & 0 & 1 & 1,000 \\
\hline 70 & Emma Suryati & 0 & 6 & 1,000 \\
\hline 71 & Enang Harris & 0 & 11 & 1,000 \\
\hline 72 & Endang Susianingsih & 0 & 5 & 1,000 \\
\hline 73 & Eni Kusrini, & 0 & 3 & 1,000 \\
\hline 74 & Erfan Andi Hendradjat & 0 & 1 & 1,000 \\
\hline 75 & Eri Setiadi & 0 & 2 & 1,000 \\
\hline 76 & Erlania & 0 & 16 & 1,000 \\
\hline 77 & $\begin{array}{l}\text { Erma Primanita } \\
\text { Hayuningtyas }\end{array}$ & 0 & 8 & 1,000 \\
\hline 78 & Erna Ratnawati & 0 & 5 & 1,000 \\
\hline 79 & $\begin{array}{l}\text { Erni Kristina } \\
\text { Pambayuningrum }\end{array}$ & 0 & 1 & 1,000 \\
\hline 80 & Erwiantono Erwiantono, & 0 & 1 & 1,000 \\
\hline 81 & Erwin N. Fahlefi & 0 & 1 & 1,000 \\
\hline 82 & Estu Nugroho & 0 & 6 & 1,000 \\
\hline 83 & Evi Tahapari & 0 & 5 & 1,000 \\
\hline 84 & $\begin{array}{l}\text { Fachriyan Hasmi } \\
\text { Pasaribu }\end{array}$ & 0 & 1 & 1,000 \\
\hline 85 & Fachrudin Fachrudin, & 0 & 3 & 1,000 \\
\hline 86 & Farah Diana, & 0 & 1 & 1,000 \\
\hline
\end{tabular}




\begin{tabular}{|c|c|c|c|c|}
\hline No. & Nama Penulis & NS & NM & C \\
\hline 87 & $\begin{array}{l}\text { Ferdinand Hukama } \\
\text { Taqwa, }\end{array}$ & 0 & 1 & 1,000 \\
\hline 88 & Fitri Husnul Khotimah, & 0 & 1 & 1,000 \\
\hline 89 & Gavin Patridge & 0 & 1 & 1,000 \\
\hline 90 & Gede S. Sumiarsa, & 0 & 1 & 1,000 \\
\hline 91 & Gigih Setia Wibawa & 0 & 1 & 1,000 \\
\hline 92 & Gleny Hasan Huwoyon, & 0 & 1 & 1,000 \\
\hline 93 & Gunarto Gunarto, & 0 & 1 & 1,000 \\
\hline 94 & Gusti Ngurah Permana, & 0 & 4 & 1,000 \\
\hline 95 & Hafrijal Syandri & 0 & 1 & 1,000 \\
\hline 96 & Hambali Supriyadi & 0 & 2 & 1,000 \\
\hline 97 & Happy Nursyam & 0 & 1 & 1,000 \\
\hline 98 & Haryanti & 0 & 11 & 1,000 \\
\hline 99 & Hasnawi & 0 & 11 & 1,000 \\
\hline 100 & Hasnawi Hasnawi & 0 & 1 & 1,000 \\
\hline 101 & Hatim Albasri & 0 & 1 & 1,000 \\
\hline 102 & Heri Wibowo & 0 & 1 & 1,000 \\
\hline 103 & Herlinah Herlinah, & 0 & 2 & 1,000 \\
\hline 104 & Hery Sulistyo & 0 & 1 & 1,000 \\
\hline 105 & Hessy Novita & 0 & 1 & 1,000 \\
\hline 106 & $\begin{array}{l}\text { Hidayat Suryanto } \\
\text { Suwoyo }\end{array}$ & 0 & 3 & 1,000 \\
\hline 107 & Hirmawan Tirta Yudha & 0 & 2 & 1,000 \\
\hline 108 & Huria Marnis & 0 & 5 & 1,000 \\
\hline 109 & I Gusti Ngurah Permana, & 0 & 4 & 1,000 \\
\hline 110 & I Nyoman Radiarta & 0 & 23 & 1,000 \\
\hline 111 & I Wayan Subamia, & 0 & 3 & 1,000 \\
\hline 112 & I.W. Teguh Wibawan & 0 & 1 & 1,000 \\
\hline 113 & Ibnu Dwi Buwono, & 0 & 2 & 1,000 \\
\hline 114 & Ibnu Rusdi, & 0 & 4 & 1,000 \\
\hline 115 & Ida Komang Wardana & 0 & 8 & 1,000 \\
\hline 116 & idil Ardi & 0 & 2 & 1,000 \\
\hline 117 & Ika Nurlaela & 0 & 1 & 1,000 \\
\hline 118 & Ikhsan Khasani, & 0 & 2 & 1,000 \\
\hline 119 & Imam Taufik & 0 & 1 & 1,000 \\
\hline 120 & Iman Rusmana & 0 & 1 & 1,000 \\
\hline 121 & Imron & 0 & 5 & 1,000 \\
\hline 122 & $\begin{array}{l}\text { Ince Ayu Khairana } \\
\text { Kadriah, }\end{array}$ & 0 & 2 & 1,000 \\
\hline 123 & Indira Fitriliyani & 0 & 1 & 1,000 \\
\hline 124 & Ing Mokoginta & 0 & 1 & 1,000 \\
\hline 125 & Inneke F.M. Rumengan & 0 & 1 & 1,000 \\
\hline 126 & Irin Iriana Kusmini, & 0 & 3 & 1,000 \\
\hline 127 & Irma Melati & 0 & 9 & 1,000 \\
\hline 128 & Iskandariah Iskandariah, & 0 & 3 & 1,000 \\
\hline 129 & Isti Koesharyani, & 0 & 3 & 1,000 \\
\hline 130 & Iswari Ratna Astuti & 0 & 1 & 1,000 \\
\hline
\end{tabular}

\begin{tabular}{|c|c|c|c|c|}
\hline No. & Nama Penulis & NS & NM & C \\
\hline 131 & Jadmiko Darmawan & 0 & 1 & 1,000 \\
\hline 132 & Jatnika Jatnika & 0 & 1 & 1,000 \\
\hline 133 & Jesmond Sammut & 0 & 1 & 1,000 \\
\hline 134 & Jhon Harianto Hutapea, & 0 & 4 & 1,000 \\
\hline 135 & Jojo Subagja, & 0 & 4 & 1,000 \\
\hline 136 & Joko Prastowo & 0 & 1 & 1,000 \\
\hline 137 & Joni Haryadi & 0 & 2 & 1,000 \\
\hline 138 & Kamaluddin Mahfudz & 0 & 1 & 1,000 \\
\hline 139 & Kamariah & 0 & 2 & 1,000 \\
\hline 140 & Kamaruddin Kamaruddin & 0 & 3 & 1,000 \\
\hline 141 & Ketut Maha Setiawati, & 0 & 4 & 1,000 \\
\hline 142 & Ketut Mahardika & 0 & 3 & 1,000 \\
\hline 143 & Ketut Sugama & 0 & 3 & 1,000 \\
\hline 144 & Ketut Suwirya, & 0 & 4 & 1,000 \\
\hline 145 & Khairul Syahputra & 0 & 9 & 1,000 \\
\hline 146 & Khumaira Puspasari & 0 & 1 & 1,000 \\
\hline 147 & Koko Kurniawan & 0 & 2 & 1,000 \\
\hline 148 & Komar Sumantadinata & 0 & 3 & 1,000 \\
\hline 149 & Kukuh Nirmala & 0 & 5 & 1,000 \\
\hline 150 & Kurniasih Kurniasih & 0 & 2 & 1,000 \\
\hline 151 & Kusdiarti Kusdiarti & 0 & 1 & 1,000 \\
\hline 152 & Lalu Mayadi & 0 & 1 & 1,000 \\
\hline 153 & Lamanto Lamanto & 0 & 2 & 1,000 \\
\hline 154 & Lida Puspaningtyas & 0 & 1 & 1,000 \\
\hline 155 & Lideman Lideman & 0 & 1 & 1,000 \\
\hline 156 & Lies Emmawati Hadie & 0 & 1 & 1,000 \\
\hline 157 & Lila Gardenia, & 0 & 3 & 1,000 \\
\hline 158 & Lili Sholichah, & 0 & 2 & 1,000 \\
\hline 159 & Linda Sugiarti & 0 & 1 & 1,000 \\
\hline 160 & M. Agus Suprayudi & 0 & 1 & 1,000 \\
\hline 161 & $\begin{array}{l}\text { M. Hunaina Fariduddin } \\
\text { Ath-thar }\end{array}$ & 0 & 1 & 1,000 \\
\hline 162 & $\begin{array}{l}\text { M. Hunaina Fariduddin } \\
\text { Ath-thar }\end{array}$ & 0 & 1 & 1,000 \\
\hline 163 & Makmur Makmur, & 0 & 3 & 1,000 \\
\hline 164 & Maria Bintang & 0 & 1 & 1,000 \\
\hline 165 & Markus Mangampa & 0 & 1 & 1,000 \\
\hline 166 & Mas Bayu Syamsunarno & 0 & 1 & 1,000 \\
\hline 167 & Mas Tri Djoko Sunarno & 0 & 2 & 1,000 \\
\hline 168 & Michael A. Rimmer & 0 & 1 & 1,000 \\
\hline 169 & Mochamad Bajar & 0 & 1 & 1,000 \\
\hline 170 & Mochamad Nurdin, & 0 & 1 & 1,000 \\
\hline 171 & Mochammad Zamroni, & 0 & 1 & 1,000 \\
\hline 172 & Mohammad Ali Syahdan & 0 & 1 & 1,000 \\
\hline 173 & Mudian Paena & 0 & 4 & 1,000 \\
\hline 174 & Mufti P. Patria & 0 & 1 & 1,000 \\
\hline
\end{tabular}




\begin{tabular}{|c|c|c|c|c|}
\hline No. & Nama Penulis & NS & NM & C \\
\hline 175 & $\begin{array}{l}\text { Muhammad Husni } \\
\text { Amarullah }\end{array}$ & 0 & 1 & 1,000 \\
\hline 176 & Muhammad Marzuqi, & 0 & 3 & 1,000 \\
\hline 177 & Muhammad Muhammad & 0 & 1 & 1,000 \\
\hline 178 & $\begin{array}{l}\text { Muhammad Yamin } \\
\text { Paada }\end{array}$ & 0 & 1 & 1,000 \\
\hline 179 & Muhammad Zairin Junior & 0 & 3 & 1,000 \\
\hline 180 & Muharijadi Atmomarsono & 0 & 1 & 1,000 \\
\hline 181 & Muliani & 0 & 5 & 1,000 \\
\hline 182 & Mulyasari Mulyasari & 0 & 5 & 1,000 \\
\hline 183 & Mun Imah Madeali, & 0 & 2 & 1,000 \\
\hline 184 & Munti Yuhana & 0 & 5 & 1,000 \\
\hline 185 & Muslimin Muslimin, & 0 & 2 & 1,000 \\
\hline 186 & Mustafa, & 0 & 3 & 1,000 \\
\hline 187 & Narita Syawalia & 0 & 1 & 1,000 \\
\hline 188 & Neltje Nobertine Palinggi & 0 & 6 & 1,000 \\
\hline 189 & Neviaty P. Zamani & 0 & 1 & 1,000 \\
\hline 190 & Ni Wayan Widya Astuti & 0 & 3 & 1,000 \\
\hline 191 & Niken T.M. Pratiwi & 0 & 1 & 1,000 \\
\hline 192 & Nina Meilisza, & 0 & 3 & 1,000 \\
\hline 193 & Ningrum Suhenda & 0 & 1 & 1,000 \\
\hline 194 & Nono Carsono, & 0 & 2 & 1,000 \\
\hline 195 & Noor Bimo Adhiyudanto & 0 & 1 & 1,000 \\
\hline 196 & Novi Megawati & 0 & 1 & 1,000 \\
\hline 197 & Nunak Nafiqoh & 0 & 1 & 1,000 \\
\hline 198 & Nunuk Listiyowati, & 0 & 3 & 1,000 \\
\hline 199 & $\begin{array}{l}\text { Nur Bambang Priyo } \\
\text { Utomo }\end{array}$ & 0 & 3 & 1,000 \\
\hline 200 & Nurbaya Nurbaya, & 0 & 4 & 1,000 \\
\hline 201 & Nurhidayat & 0 & 7 & 1,000 \\
\hline 202 & Nyoman Adiasmara Giri & 0 & 1 & 1,000 \\
\hline 203 & O.D. Subakti Hasan & 0 & 1 & 1,000 \\
\hline 204 & Odang Carman & 0 & 2 & 1,000 \\
\hline 205 & Ofri Johan, & 0 & 4 & 1,000 \\
\hline 206 & Otong Zenal Arifin & 0 & 4 & 1,000 \\
\hline 207 & Philip Teguh Imanto & 0 & 1 & 1,000 \\
\hline 208 & Priadi Setyawan, & 0 & 4 & 1,000 \\
\hline 209 & Qoriah Saleha & 0 & 1 & 1,000 \\
\hline 210 & R.R. Pudji Sinarni Dewi & 0 & 7 & 1,000 \\
\hline 211 & $\begin{array}{l}\text { Rachmansyah } \\
\text { Rachmansyah }\end{array}$ & 0 & 10 & 1,000 \\
\hline 212 & Rani Hafsaridewi & 0 & 1 & 1,000 \\
\hline 213 & Rarastoeti Pratiwi & 0 & 1 & 1,000 \\
\hline 214 & Rasidi Rasidi & 0 & 1 & 1,000 \\
\hline 215 & Ratu Siti Aliah & 0 & 1 & 1,000 \\
\hline 216 & Regina Melianawati & 0 & 1 & 1,000 \\
\hline 217 & Rendy Ginanjar & 0 & 1 & 1,000 \\
\hline
\end{tabular}

\begin{tabular}{|c|c|c|c|c|}
\hline No. & Nama Penulis & NS & NM & C \\
\hline 218 & Retno Andamari & 0 & 2 & 1,000 \\
\hline 219 & Reza Samsudin & 0 & 1 & 1,000 \\
\hline 220 & Rezki Antoni Suhaimi & 0 & 5 & 1,000 \\
\hline 221 & Rina Astuti & 0 & 1 & 1,000 \\
\hline 222 & Rina Hirnawati, & 0 & 2 & 1,000 \\
\hline 223 & Rinny Modaso & 0 & 1 & 1,000 \\
\hline 224 & Ristanti Frinra Daud, & 0 & 2 & 1,000 \\
\hline 225 & Rita Febrianti & 0 & 1 & 1,000 \\
\hline 226 & Rohama Daud & 0 & 1 & 1,000 \\
\hline 227 & Rommy Suprapto & 0 & 5 & 1,000 \\
\hline 228 & Ruby Vidia Kusumah, & 0 & 3 & 1,000 \\
\hline 229 & Rudhy Gustiano, & 0 & 4 & 1,000 \\
\hline 230 & Rusman Rusman & 0 & 1 & 1,000 \\
\hline 231 & Rustadi Rustadi & 0 & 1 & 1,000 \\
\hline 232 & Ruzkiah Asaf & 0 & 1 & 1,000 \\
\hline 233 & S. Permana & 0 & 1 & 1,000 \\
\hline 234 & $\begin{array}{l}\text { S.R. Hesti } \\
\text { Mulyaningrum, }\end{array}$ & 0 & 2 & 1,000 \\
\hline 235 & Sabara Putra & 0 & 1 & 1,000 \\
\hline 236 & Saepudin & 0 & 1 & 1,000 \\
\hline 237 & Samuel Lante & 0 & 5 & 1,000 \\
\hline 238 & $\begin{array}{l}\text { Sari Budi Moria } \\
\text { Sembiring }\end{array}$ & 0 & 11 & 1,000 \\
\hline 239 & Sari Dwi Maryanti & 0 & 1 & 1,000 \\
\hline 240 & Sawung Cindelaras & 0 & 1 & 1,000 \\
\hline 241 & Sigit Budileksono & 0 & 1 & 1,000 \\
\hline 242 & Siti Fatimah & 0 & 1 & 1,000 \\
\hline 243 & Siti Murniasih & 0 & 3 & 1,000 \\
\hline 244 & Siti Narwiyani & 0 & 1 & 1,000 \\
\hline 245 & Siti Subandiyah & 0 & 1 & 1,000 \\
\hline 246 & Siti Subandiyah, & 0 & 3 & 1,000 \\
\hline 247 & $\begin{array}{l}\text { Siti Zuhriyyah Musthofa, } \\
\text { S }\end{array}$ & 0 & 1 & 1,000 \\
\hline 248 & Sophia Lasma Sagala & 0 & 1 & 1,000 \\
\hline 249 & Sri Murtini & 0 & 1 & 1,000 \\
\hline 250 & Sri Nuryati & 0 & 2 & 1,000 \\
\hline 251 & Sri Sundari & 0 & 1 & 1,000 \\
\hline 252 & Sudewi & 0 & 2 & 1,000 \\
\hline 253 & Suharsono & 0 & 4 & 1,000 \\
\hline 254 & Sukarman Sukarman, & 0 & 2 & 1,000 \\
\hline 255 & Sukenda Sukenda & 0 & 11 & 1,000 \\
\hline 256 & Suko Ismi, & 0 & 2 & 1,000 \\
\hline 257 & Sularto & 0 & 5 & 1,000 \\
\hline 258 & Sumoharjo & 0 & 1 & 1,000 \\
\hline 259 & Sunaryo & 0 & 1 & 1,000 \\
\hline 260 & Susila & 0 & 1 & 1,000 \\
\hline
\end{tabular}




\begin{tabular}{|c|c|c|c|c|}
\hline No. & Nama Penulis & NS & NM & C \\
\hline 261 & Sutanti & 0 & 1 & 1,000 \\
\hline 262 & Suwardi Tahe & 0 & 1 & 1,000 \\
\hline 263 & Syaifullah Syaifullah & 0 & 1 & 1,000 \\
\hline 264 & Syamsu Alam Ali & 0 & 1 & 1,000 \\
\hline 265 & Syarifuddin Tonnek & 0 & 3 & 1,000 \\
\hline 266 & $\begin{array}{l}\text { Tarunamulia } \\
\text { Tarunamulia, }\end{array}$ & 0 & 2 & 1,000 \\
\hline 267 & Tatam Sutarmat, & 0 & 2 & 1,000 \\
\hline 268 & Tatik Mufidah, & 0 & 3 & 1,000 \\
\hline 269 & Taukhid Taukhid & 0 & 7 & 1,000 \\
\hline 270 & Titiek Aslianti, & 0 & 2 & 1,000 \\
\hline 271 & Titin Kurniasih & 0 & 5 & 1,000 \\
\hline 272 & Tony Setiadharma & 0 & 2 & 1,000 \\
\hline 273 & Tri Heru Prihadi & 0 & 1 & 1,000 \\
\hline 274 & Turmuzi Tammi & 0 & 1 & 1,000 \\
\hline 275 & Tuti Sumiati & 0 & 5 & 1,000 \\
\hline 276 & Tutik Kadarini, & 0 & 2 & 1,000 \\
\hline 277 & Ulia Fajriah & 0 & 1 & 1,000 \\
\hline 278 & Uni Purwaningsih & 0 & 8 & 1,000 \\
\hline 279 & Usman & 0 & 10 & 1,000 \\
\hline 280 & Utojo & 0 & 4 & 1,000 \\
\hline 281 & Utut Widyastuti & 0 & 5 & 1,000 \\
\hline 282 & Vitas Atmadi Prakoso, & 0 & 2 & 1,000 \\
\hline 283 & Wahyulia Cahyanti & 0 & 1 & 1,000 \\
\hline 284 & Wartono Hadie & 0 & 5 & 1,000 \\
\hline 285 & Wawan Andriyanto, & 0 & 4 & 1,000 \\
\hline 286 & Widanarni Widanarni, & 0 & 2 & 1,000 \\
\hline 287 & Windarti Windarti & 0 & 1 & 1,000 \\
\hline 288 & Wiwien Mukti Andriyani & 0 & 1 & 1,000 \\
\hline 289 & $\begin{array}{l}\text { Wiwin Kusuma Atmaja } \\
\text { Putra }\end{array}$ & 0 & 1 & 1,000 \\
\hline 290 & Yani Aryati & 0 & 1 & 1,000 \\
\hline 291 & Yasmina Nirmala Asih & 0 & 1 & 1,000 \\
\hline 292 & Yenny Risjani & 0 & 1 & 1,000 \\
\hline 293 & Yogi Himawan & 0 & 1 & 1,000 \\
\hline 294 & Yuke Eliyani & 0 & 1 & 1,000 \\
\hline 295 & Yuniar Mulyani & 0 & 1 & 1,000 \\
\hline 296 & Zafril Imran Azwar & 0 & 8 & 1,000 \\
\hline 297 & Zulkifli Zulkifli & 0 & 1 & 1,000 \\
\hline 298 & $\begin{array}{l}\text { Angela Mariana } \\
\text { Lusiastuti }\end{array}$ & 1 & 17 & 0,944 \\
\hline 299 & Irsyaphiani Insan & 1 & 0 & 0,000 \\
\hline 300 & Isriansyah Isriansyah & 1 & 0 & 0,000 \\
\hline 301 & Wahyu Pamungkas & 1 & 0 & 0,000 \\
\hline \multicolumn{2}{|r|}{ Jumlah } & 4 & 807 & 0,995 \\
\hline
\end{tabular}

Tabel. 4 di atas menggambarkan perbandingan antara peringkat produktivitas dan peringkat kolaborasi dalam Jurnal Riset Akuakultur tahun 2011-2015 berjumlah 301 penulis. Berdarkan rumus Subramanya (1983) dapat diketahui jumlah $\mathrm{C}=0$ sebanyak 3 penulis, $0<\mathrm{C}<0,5$ sebanyak 0 penulis, $\mathrm{C}=$ 0,5 sebanyak 0 penulis, $0,5<C<1$ sebanyak 1 penulis dan $\mathrm{C}=1$ sebanyak 297 penulis dengan rata-rata kolabarasi sebesar 0,995

Berdasarkan Tabel 4 nilai rata-rata tingkat kolaborasi antara kedua parameter tersebut menunjukkan peringkat yang sangat tinggi bahkan boleh dikatakan sempurna yaitu sebesar 0,995. Artinya semakin sering peneliti berkolaborasi maka kualitas dalam Jurnal Riset Akultur 20112015 semakin tinggi kualitas penelitian yang dihasilkan.

\section{KESIMPULAN}

Berdasarkan hasil analisis dan pembahasan aspek produktivitas dan tingkat kolaborasi penulis, maka dapat dambil kesimpulan sebagai berikut:

1. Penulis yang paling produktif yang termuat dalam buku Jurnal Riset Akuakultur adalah I Nyoman Radiarta (23 artikel) dan kemudian oleh Angela. Mariana Lusiastuti (18 artikel)

2. Dari 301 penulis yang melakukan kolaborasi, frekuensi kolaborasi I Nyoman Radiarta merupakan penulis yang paling banyak melakukan kolaborasi dengan penulis lain (23 artikel), kemudian oleh Angela. Mariana Lusiastuti (18 artikel) penulisan.

3. Penelitian ini menujukkan bahwa tingkat kolaborasi antara kedua parameter tersebut menunjukkan peringkat yang sangat tinggi bahkan boleh dikatakan positif yaitu sebesar 0,995. Artinya semakin sering peneliti berkolaborasi maka kualitas dan kualitas dalam Jurnal Riset Akultur 20112015 semakin tinggi kualitas penelitian yang dihasilkan

\section{DAFTAR PUSTAKA}

Suraji, A. 2011. 10 Ciri-ciri Jurnal IImiah.http:// widyagama.ac.id/ajisuraji/wp-content/ uploads/2011/12/10-CIRI-CIRI-JURNALILMIAH.pdf. Diakses 2 April 2017 
Alwasilah, Chaedar dan Senny Suzanna Alwasilah 2007 Pokoknya Menulis: Cara Baru Menulis dengan Metode Kolaborasi. Bandung: Kiblat Buku Utama

Aliyu, M. 2011. Author Productivity and ColaborationAmong Academic Scientists in ModibboAdama University of Technology, Yola. The Information Manager, Vol. 11(1\&2):32-35.

Dewiyana, Himma. 2010. Produktivitas Pengarang pada Jurnal Program Studi di Lingkungan Universitas Sumatera Utara (USU) Terbitan USU Press Tahun 2004-2006. http:// digilibunsri.wordpress.com/2010/03/04/ produktivitas-pengarangpada-jurnal-programstudi-di-lingkungan-universitas-sumaterautara-usuterbitan-usu-press-tahun-20042006-oleh-himma-dewiyana-dan-fitriarianti/ diakses 9 April 2017

Hakim. 2012. Penyusunan Karya Tulis IImiah. http://aminawm.wordpress.com/pe ngertianjurnal-ilmiah/. Diakses 2 April 2017

Harande, Y.I. 2001. Author Productivity andCollaboration: an Investigation of the Relationship Using the Literature of Technology. Libri, vol. 51: 124-127.

Hasugian, J. \& Ishak. 2009. Analisis bibliometrikterhadap publikasi hasil penelitianAIDS di Indonesia. Laporan Penelitian.Universitas Sumatera Utara, Medan. 24 hal.

Indonesia. 2012. Pedoman Penerbitan Buku. Jakarta (ID): LIPI Press. http://intra.geotek. lipi.go.id. Diakses tanggal 6 Maret 2017

Katz, J.S and Martin,B.R, 1997. What is research collaboration.In research policy, Research Policy, 26: 1-18.

Maryono. 2012. Tren impactfactor, produktivitas, dan kolaborasi dalam Indonesian Journalof Chemistry. IPTEK-KOM, Vol. 14(2):115-132.
Marusic, M., Marusic, A., 2009. The purpose of scientific journals: small is important. The Journal of Tehran University Heart Center 4, 143-147.

Prihantono, I.G. 2002. Graf Komunikasi. Kumpulan kursus bibliometrika. Universitas Indonesia, Jakarta

Pusat Penelitian Biologi. 2012. Laporan Tahunan Pusat Penelitan Biologi-LIPI. Cibinong. 105 hal

Wulan, Sri. 2014. Produktivitas dan tingkat kolaborasi penulis dalam karya tulis ilmiah peneliti bidang zoologi Puslit Biologi Lipi 2005-2010, Majalah Visi Pustaka vol Vol.16 No.2 - Agustus 2014: 176-184

Sormin, Remi. 2009. Kajian Korelasi Antara Kolaborasi Peneliti dan Produktifitas Peneliti Lingkup Badan Litbang Pertanian. Mei 29, 2013. http://pustaka.litbang.deptan.go.id/ publikasi/ pp181091.pd diakses 6 Maret $\underline{2017}$

Subramanyam, K. 1983. Bibliometric studies ofresearch collaboration: a review. Journalof Information Science, 6: 33-38

Sukmadinata , 2006. Metode Penelitian Pendidikan, Remaja Rosdakarya, Bandung

Sulistyo,Basuki 2002. Bibliometrics, scientometrics dan infometrics. Kumpulan kursus bibliometika. Universitas Indonesia, Jakarta.

Sulistyo, Basuki (1991) Pengantar IImu Perpustakaan. Gramedia Utama, Jakarta

Wulan, Sri. 2014. Produktivitas dan tingkat kolaborasi penulis dalam karya tulis ilmiah peneliti bidang zoologi Puslit Biologi Lipi 2005-2010, Majalah Visi Pustaka Vol.16 No.2 - Agustus 2014: 176-184 